\title{
Correction: Reliable transgene-independent method for determining sleeping beauty transposon copy numbers
}

\author{
Orsolya Kolacsek', Virág Krízsik, Anita Schamberger', Zsuzsa Erdei ', Ágota Apáti', György Várady ${ }^{1}$, Lajos Mátés², \\ Zsuzsanna Izsvák ${ }^{2,3}$, Zoltán Ivics ${ }^{2,3}$, Balázs Sarkadi ${ }^{1}$ and Tamás I Orbán ${ }^{*}$
}

\section{Correction}

After the publication of our article [1], the authors noticed two typing errors in the 'Methods' part of the original article:

- in Table two, the correct sequence of RPPH1 / Probe is 2 nucleotides longer at the 3 ' end, so it is: CACTCCCATGTCCCTT ;

- in the penultimate sentence of the 'Quantitative real-time PCR' section, the concentrations of the primers and the probe were switched so the correct sentence should be: "Final concentrations of primers and probes were 900 and $250 \mathrm{nM}$, respectively."

The authors apologize for these unintended mistakes in the text.

\section{Competing interests}

The authors declare that they have no competing interests.

\section{Authors' contributions}

OK established the HEK clones, OK and VK optimized the real-time PCR and performed copy number measurements, AS, ZE and AA established the HUES9 clones, GV helped in FACS measurements, LM measured copy numbers in HeLa clones, Zsl and ZI gave technical help and advices with the SB transposon work, BS provided financial support and discussed the data and $\mathrm{TIO}$ designed the overall strategy, analyzed the data and wrote the paper. All authors read and approved the final manuscript.

\section{Author details}

'Membrane Research Group of the Hungarian Academy of Sciences, Semmelweis University and National Blood Center, Budapest, Hungary. ${ }^{2}$ Mobile DNA Group, Max-Delbrück Center for Molecular Medicine, Berlin, Germany. ${ }^{3}$ University of Debrecen, Debrecen, Hungary.

Received: 20 December 2012 Accepted: 20 December 2012 Published: 15 March 2013

\footnotetext{
* Correspondence: orbant@biomembrane.hu

'Membrane Research Group of the Hungarian Academy of Sciences, Semmelweis University and National Blood Center, Budapest, Hungary Full list of author information is available at the end of the article
}

\section{References}

1. Kolacsek O, Krízsik V, Schamberger A, Erdei Z, Apáti Á, Várady G, Mátés L, Izsvák Z, Ivics Z, Sarkadi B, Orbán Tl: Reliable transgene-independent method for determining Sleeping Beauty transposon copy numbers. Mob DNA 2011, 2:5.

doi:10.1186/1759-8753-4-11

Cite this article as: Kolacsek et al:: Correction: Reliable transgeneindependent method for determining sleeping beauty transposon copy numbers. Mobile DNA 4:11.

\section{Submit your next manuscript to BioMed Central and take full advantage of: \\ - Convenient online submission \\ - Thorough peer review \\ - No space constraints or color figure charges \\ - Immediate publication on acceptance \\ - Inclusion in PubMed, CAS, Scopus and Google Scholar \\ - Research which is freely available for redistribution

